\title{
${ }^{\odot A . ~ С . ~ С а д у л л а є в, ~ М . ~ В . ~ М е д в е д є в ~}$ \\ ДЗ «Дніпропетровсъка медична акаделія МОЗ Украӥни» \\ ЕНДОМЕТРІОМИ ЯЄЧНИКІВ І ОВАРІАЛЬНИЙ РЕЗЕРВ (ОГЛЯД ЛІТЕРАТУРИ)
}

Мета роботи - збір та аналіз даних світової літератури щодо проблеми впливу ендометріоїдних кіст на оваріальний резерв у жінок фрертильного віку і вибір оптимальних методів оцінки оваріального резерву, а також вибір хірургічних технологій для лікування ендометріом із можливістю збереження оваріального резерву для здійснення репродуктивної функції у жінок.

Ендометріоз $є$ однією з проблем сучасної репродуктивної медицини, оскільки він може бути причиною безпліддя у 50 \% випадків. Ендометріоми яєчників складають 35 \% всіх доброякісних кіст яєчників і зустрічаються у 17-44 \% жінок 3 ендометріозом. В 1/3 випадків ендометріоми представлені двосторонньою локалізацією, що в рази погіршує прогноз репродуктивних планів. Походження ендометріоми та ії негативний вплив на оваріальний резерв пояснюється складним і неоднозначним патогенезом. Вибір діагностичних методів для оцінки стану оваріального резерву в жінок з ендометріомою, які планують вагітність, є важливим, оскільки за їх допомогою можна прогнозувати ризики до і після хірургічного пошкодження оваріального резерву, що дає можливість гінекологу вибрати хірургічний метод лікування, а також планувати ДРТ. Лапароскопічний стрипінг капсули едометріоїдної кісти є золотим стандартом лікування цих кіст. Однак цей метод може призвести до необоротного пошкодження оваріального резерву, що ставить під загрозу репродуктивні плани жінки. Цей негативний вплив хірургічного втручання можна мінімізувати за допомогою PRP-терапії з аутологічної крові. Плазма, збагачена тромбоцитами (platelet rich plasma - PRP), являє собою концентроване джерело тромбоцитів, отримане 3 венозної крові після її центрифругування. PRP як унікальна система, що містить в собі більше 800 біологічно активних речовин, може сприяти розвитку примордіальних і первинних фролікулів до преантральної стадії. Ще одним перспективним методом лікування ендометріом з мінімізованим впливом на тканину яєчника, отже, і на оваріальний резерв є склеротерапія з етанолом, яку можна застосовувати як при первинних, так і рецидивних ендометріомах.

Ключові слова: ендометріома; антимюллерів гормон; АМГ; підрахунок антральних фролікулів; пАФ; лапароскопія; склеротерапія; PRP-терапія; оваріальний резерв.

\section{ЭНДОМЕТРИОМЫ ЯИЧНИКОВ И ОВАРИАЛЬНЫЙ РЕЗЕРВ (ОБЗОР ЛИТЕРАТУРЫ)}

Цель работы - сбор и анализ данных мировой литературы относительно проблемы влияния эндометриоидных кист на овариальный резерв у женщин фертильного возраста и выбор оптимальных методов оценки овариального резерва, а также выбор хирургических технологий для лечения эндометриом с возможностью сохранения овариального резерва для осуществления репродуктивной фрунции у женщин.

Эндометриоз является одной из проблем современной репродуктивной медицины, так как он может быть причиной бесплодия в 50 \% случаев. Эндометриомы яичников составляют 35 \% всех доброкачественных кист яичников и встречаются у 17-44 \% женщин с эндометриозом. В 1/3 случаев эндометриомы представлены двусторонней локализацией, что в разы ухудшает прогноз репродуктивных планов. Происхождение эндометриомы и ее негативное влияние на овариальный резерв объясняется сложным и неоднозначным патогенезом. Выбор диагностических методов для оценки состояния овариального резерва у женщин с эндометриомой, планирующих беременность, является немаловажным, так как с их помощью можно прогнозировать риски до и после хирургического повреждения овариального резерва, что дает возможность гинекологу избрать хирургический метод лечения, а также планировать ВРТ. Лапароскопический стриппинг капсулы эндометриоидной кисты является золотым стандартом лечения этих кист. Однако этот метод может привести к необратимому повреждению овариального резерва, что ставит под угрозу репродуктивные планы женщины. Это негативное влияние хирургического вмешательства можно минимизировать с помощью PRP-терапии из аутологической крови. Плазма, обогащенная тромбоцитами (platelet rich plasma - PRP), представляет собой концентрированный источник тромбоцитов, полученный из венозной крови после ее центрифугирования. PRP как уникальная система, содержащая в себе более 800 биологически активных веществ, может способствовать развитию примордиальных и первичных фолликулов до преантральной стадии. Еще одним перспективным методом лечения эндометриом с минимизированным влиянием на ткань яичника, следовательно, и на овариальный резерв является склеротерапия с этанолом, которую можно использовать как при первичных, так и рецидивирующих эндометриомах.

Ключевые слова: эндометриома; антимюллеров гормон; АМГ; подсчет антральных фолликулов; ПАФ; лапароскопия; склеротерапия; PRP-терапия; овариальный резерв.

\section{ENDOMETRIOMAS AND OVARIAN RESERVE (LITERATURE REVIEW)}

The aim of the study - to collect and analyze world literature data on the problem of the influence of endometriotic cysts on the ovarian reserve in women of fertile age and the choice of optimal methods for assessing the ovarian reserve, as well as the choice of surgical technologies for the treatment of endometriomas with the possibility of maintaining the ovarian reserve for reproductive function in women.

Endometriosis is one of the problems of modern reproductive medicine, since it can cause infertility in $50 \%$ of cases. Ovarian endometriomas account for $35 \%$ of all benign ovarian cysts and are found in 17-44 \% of women with endometriosis. In 1/3 of cases, endometriomas are represented by bilateral localization, which significantly worsens the prognosis of reproductive plans. The origin of the endometrioma and its negative effect on the ovarian reserve is explained by a complex and ambiguous pathogenesis. The choice of diagnostic methods for assessing the condition of the ovarian reserve in women with pregnancy planning endometrioma 
is important, since they can be used to predict the risks before and after surgical damage to the ovarian reserve, which allows the gynecologist to choose a surgical treatment method and also plan for ART. Laparoscopic stripping of the capsule of the endometrial cyst is the "gold standard" for the treatment of these cysts. However, this method can lead to irreversible damage to the ovarian reserve, which jeopardizes the woman's reproductive plans. This negative impact of surgical intervention can be minimized with PRP therapy from autologous blood. Platelet rich plasma (PRP) is a concentrated platelet source obtained from venous blood after centrifugation. PRP as a unique system containing more than 800 biologically active substances can contribute to the development of primary and primary follicles to the preantral stage. Another prescriptive method for treating endometriomas with a minimized effect on the ovarian tissue, therefore, on the ovarian reserve, is sclerotherapy with ethanol, which can be used both in primary and relapsed endometriomas.

Key words: endometrioma; anti-Mullerian hormone; AMH; antral follicle count; AFC; laparoscopy; sclerotherapy; PRP-therapy; ovarial reserve.

Ендометріоз досі залишається одним із загадкових захворювань репродуктивної системи. Він $€$ широко відомою причиною 50 \% безпліддя і $60 \%$ тазового болю у жінок репродуктивного віку [1-3]. Яєчники є однією із поширених локалізацій ендометріозу [4]. Ендометріоми яєчників складають 35 \% всіх доброякісних кіст яєчників, зустрічаються у 17-44 \% жінок з ендометріозом і є частою причиною безпліддя та болю в малому тазі $[5,6]$. В 1/3 випадків ендометріоми є двобічними [7].

Патогенез ендометріоми яєчника складний, неоднозначний, і його походження пояснюється такими теоріями [8]: відбувається інверсія і подальша прогресуюча інвагінація кори яєчника ендометріоїдними імплантатами з утворенням кістозної порожнини і подальшим заповненням її гемолізованою кров'ю [9]; епітелій, що покриває яєчник, який є мезотелієм, може інвагінуватися в корі яєчника з подальшою ендометріоїдною метаплазією цього целомічного епітелію [10]; в деяких випадках відбувається ендометріоїдна трансформація функціональних кіст [11].

Активні клітини ендометрія, імплантовані на поверхню яєчника, з матриксу виділяють металопротеїнази, які здатні лізувати позаклітинний матрикс. Тим самим дозволяють ектопічним клітинам проникати в яєчник, приводячи до руйнування здорової тканини [12]. Ця активація матриксних металопротеїназ опосередковується тенасцином, який модифікує клітинну адгезію [13]. Крім того, фролікулярна рідина яєчника сама по собі може потенційно стимулювати ріст клітин ендометрія [14]. Це доводиться тим, що високі концентрації інгібіну А, інгібіну В й активіну А у фолікулярній рідині здатні стимулювати ріст і диференціювання ендометріотичних клітин [15].

Оваріальний резерв і ендометріоз

Під оваріальним резервом розуміють ффункціональний резерв яєчника, який визначає здатність яєчника до адекватної відповіді на оваріальну стимуляцію з розвитком здорового фолікула з повноцінною яйцеклітиною. Оваріальний резерв відображає кількість фролікулів, що містяться в яєчниках (примордіальний пул і зростаючі фролікули) і залежить від фрізіологічних та патофрізіологічних чинників.

Оваріальний резерв виснажується протягом життя жінки, і швидкість виснаження залежить як від зовнішніх, так і від внутрішніх чинників. До 20-го тижня гестації у плода жіночої статі кількість оогоніїв становить 6-7 мільйонів. При народженні ця кількість зменшується до 1-2 мільйонів. До періоду статевого дозрівання це число зменшується до 300000 - 500 000. До 37 років - 25000 і до 51 року знижується до $1000[16,17,18]$. Дана хронологія подій залежно від віку з поступовим виснаженням ова- ріального резерву відбувається у фрізіологічних умовах, даючи можливість жінці здійснити фрертильну фрункцію, як зазначено вище. Але такий патологічний срактор, як, наприклад, ендометріоїдний процес, що відбувається в тканинах яєчника, призводить до передчасного виснаження «дорогого» в біологічному відношенні для фрертильності фролікулярного резерву.

Наявні молекулярні, гістологічні та морфологічні дослідження показали, що ендометріоз шкідливий для яєчників [19]. Тривалий ендометріоз яєчників супроводжується постійним запаленням, що приводить до фріброзу кори яєчника і тим самим до втрати фролікулів та метаплазії гладком'язових клітин [20]. Крім цього, сама наявність ендометріоми з її вмістом механічно розтягує тканину яєчника, що призводить до утруднення кровообігу або порушення васкуляризації тканини за рахунок компресії кори яєчника [21]. Було висловлено думку, що запальні реакції, пов'язані з ендометріозом, можуть відігравати роль у пошкодженні тканини яєчника і фролікулів. Оскільки первинні фолікули не мають власної судинної мережі, а стромальні клітини навколо цих фролікулів $€$ важливими медіаторами живлення і молекулярної передачі сигналів, наявність здорової специфічної для кори строми має важливе значення для розвитку ранніх фолікулів [22, 23].

Рідина ендометріодної кісти містить у собі високі концентрації таких речовин, як вільне залізо, активні срорми кисню, молекули запалення і протеолітичні ферменти, що є токсичними для навколишньої тканини $[19,24]$. Ці речовини, проникнувши в навколишні тканини, викликають фріброз, метаплазію гладких м'язів і, як наслідок, зменшують специфічну для кори строму та призводять до втрати фролікулів [25, 26]. Кора яєчника навколо ендометріом має вищий рівень окисного стресу, ніж кора навколо інших доброякісних кіст яєчника [27]. Кітайіма і співавт. [28] відзначали, що кількість фролікулів у яєчнику, де локалізована ендометріома, значно нижча, ніж у контралатеральному інтактному яєчнику [28, 29]. На підставі цих даних авторами було описано так звану гіпотезу «вигорання» з прискореним виснаженням фролікулів і атрезією в ранніх фролікулах, виявлених у яєчниках $з$ ендометріомою. Вогнищеве запалення призводить до структурної зміни кори яєчника, з масивним сріброзом і втратою специсрічної строми кори яєчника. Фіброз ендометріоїдної кісти також часто описується в роботі інших дослідників [30, 31], хоча цього не відзначено в разі дермоїдних і серозних кіст, коли кора яєчника, здавалося, тільки розтягувалася кістою і при цьому не пошкоджувалася. 
Оцінка оваріального резерву

Важливим елементом дослідження стану яєчників $€$ вибір адекватних показників оваріального резерву яєчників [32].

На сьогодні в літературі згадуються такі маркери оваріального резерву, як естрадіол (Е2), сролікулостимулюючий гормон (ФСГ), інгібін В, антимюллерів гормон (АМГ) в сироватці крові та підрахунок кількості антральних фролікулів (ПАФ) за допомогу УЗД [32, 33]. Але деякі з них вважаються непрямими, оскільки вони вимагають стимуляції або залежать від гальмування зворотного гормонального зв'язку, або залежать від циклу стимуляції і тим самим не $є$ зручними й точними для визначення справжнього стану оваріального резерву.

Із прямих маркерів і рекомендованих американським товариством репродуктивної медицини як біохімічний скринінговий тест оваріального резерву є АМГ. Переваги використання АМГ в тому, що його аналіз може бути виконаний у будь-який час менструального циклу і не залежить від застосування гормональних препаратів [34], тим самим роблячи його унікальним біохімічним маркером оваріального резерву. Було визнано, що маркер АМГ чутливий до пулу первинних фролікулів яєчника і є стабільним протягом менструального циклу [35].

АМГ - це глікопротеїн із сімейства трансформуючого фактора росту- $\beta$, вивільняється клітинами гранульози дрібних зростаючих фролікулів [36, 37]. У плода яєчники починають виробляти АМГ із 36 тижня внутрішньоутробного розвитку [38]. Починаючи з підліткового віку і до 25 років його рівень підвищується й досягає свого піку, після чого поступово знижується і доходить до невизначених рівнів у пременопаузі. Експресія АМГ ініціюється набором первинних фолікулів, і пік його експресії відбувається в преантральних і малих антральних фролікулах. АМГ є провідним регулятором раннього фолікулогенезу, оскільки він пригнічує витрачання первинних фоолікулів із первинного пулу, тим самим запобігаючи швидкому виснаженню і переходу одномоментно усіх ранніх фолікулів у фразу зростання під дією ФСГ, а також пригнічує ароматазу [39, 40].

У ФСГ-залежних стадіях росту фолікулів і в атретичних фолікулах АМГ вже не секретується [41]. На відміну від рівнів ФСГ, експресія АМГ має тільки незначні внутрішньота міжциклові коливання, а при вимірюванні, незалежно від дня менструального циклу, рівні АМГ в сироватці не відрізняються $[42,43]$. Серед усіх резервних тестів яєчників АМГ вважають найбільш раннім і найбільш чутливим. Він сильно корелює з пулом первинних фолікулів. Встановлено, що варіації периферійних рівнів АМГ протягом менструального циклу відбуваються паралельно з варіаціями ПАФ. Це означає, що внутрішньоциклічні варіації АМГ можуть бути пов'язані зі змінами числа антральних сролікулів [44]. Оскільки пул малих антральних фролікулів, підрахованих ПАФ при УЗД, є тим же, що секретує АМГ, то він пропорційний загальній кількості первинних фролікулів у яєчниках. ПАФ і АМГ мають високу кореляцію і показують подібні значення у відображенні кількості ооцитів [45]

\section{ПАФ}

На сьогодні ультразвукове дослідження є доступним та неінвазивним методом оцінки оваріального резерву. Воно відіграє важливу роль в оцінці оваріального резерву та моніторингу відповіді яєчників на стимуляцію. Для підрахунку кількості антральних фолікулів (ПАФ) проводиться трансвагінальне УЗД, як правило, на 2-5-й день менструального циклу. Шляхом візуалізації обох яєчників ручним способом визначаються всі маленькі антральні фолокули діаметром від 2 до 10 мм [32, 41, 46].

Починаючи з ранньої антральної стадії, фролікулогенез стає циклічним, причому дозрівання залежить від хвиль ФСГ та інших чинників [47]. Отже, підрахунок ПАФ зазвичай виконується на початку циклу. Однак останні дані свідчать про те, що підрахунок ПАФ можна провести безпомилково у будь-який день циклу [48]. 3 поліпшенням роздільної здатності ультразвукових апаратів і появою можливості отримання тривимірної картини, можна підрахувати антральні сролікули діаметром до 2 мм [32]. Але при цьому не було показано, що тривимірна візуалізація якось покращує клінічні результати порівняно зі стандартною двовимірною візуалізацією [49]. Важливо вказати, що вибір ультразвукового апарата також впливає на якість зображення [32, 49]. Основними недоліками ПАФ $є$ те, що цей метод оцінки залежить від апарата й оператора. Це можна побачити при порівнянні результатів як між центрами, так і всередині одного центру, де проводився підрахунок ПАФ [50, 51, 33]. До факторів, які слід враховувати при стандартизації підрахунку ПАФ, належать часові характеристики проведення УЗД для підрахунку ПАФ (2-5-й дні менструального циклу або орального контрацептивного циклу); розмір включених у підрахунок сролікулів (фролікули діаметром 2-10 мм); використовувана ультразвукова техніка (для забезпечення адекватної роздільної здатності); систематичний процес підрахунку антральних сролікулів і послідовне навчання персоналу [32, 33].

Порівняння АМГ і ПАФ як маркерів оваріального резерву

Як вже зазначалося вище, існує сильна кореляція між ПАФ і АМГ [44]. В останні роки з'явилися дані, що підтверджують рівень ПАФ і АМГ як бажаних методів для оцінки й прогнозування резерву яєчників, тому що АМГ і ПАФ є ефрективними й рівнозначними предикторами для оцінки оваріального резерву, особливо в тих жінок, у яких вкрай низькі показники оваріального резерву [33, 45, 52, 53]. Ці методи забезпечують пряме і точне вимірювання пулу фролікулів яєчника [54]

Якщо порівняти як методи оцінки стану оваріального резерву АМГ із ПАФ, то АМГ має переваги, тому що має дуже невелику варіабельність всередині і між циклами $[33,42]$

Недавній метааналіз показав, що при ендометріомах АМГ є більш відповідним біомаркером резерву яєчника, ніж ПАФ, оскільки низький рівень АМГ означає коротшу репродуктивну тривалість життя жінки [55].

Лапароскопія та оваріальний резерв

Хірургія відіграє основну роль в лікуванні ендометріом [56]. Лапароскопічну ексцизію ендометріом вважають 30лотим стандартом для хірургічного лікування цих кіст [57]. Однак втрата яєчникового резерву, завдана хірургічним втручанням, являє собою серйозну проблему в балансі між репродуктивними перевагами і ризиками, оскільки видалення стінки кісти призводить до втрати паренхіми яєчника $[58,59]$. І ця втрата фолокулярного пулу, пов'язана 3 хірургічним лікуванням, трапляється у жінок, які перенесли лапароскопічну цистектомію, де спостерігається 
нижча концентрація АМГ після перенесеної операції [60]. Відсутність чіткої площини розщеплення між кістою і стромою яєчника може привести до ненавмисного видалення кори яєчника і втрати фролікулів із потенційним зменшенням фролікулярного резерву, і це є основною проблемою хірургічного лікування ендометріом [61].

Крім того, застосування електрокоагуляції під час хірургічного лікування ендометріом порівняно з застосуванням шовного матеріалу для гемостазу призводить до додаткового пошкодження оваріального резерву, що також знижує такий прямий маркер оваріального резерву, як АМГ [62, 63, 64].

Оскільки зниження рівнів АМГ у пацієнтів з ендометріомами $€$ значним порівняно з пацієнтами 3 іншими кістами яєчника, вчені підтверджують гіпотезу про те, що наявність ендометріоми сама по собі може бути причиною зниження рівня АМГ у пацієнтів з ендометріомами яєчників. Це зниження, мабуть, викликано розтягуванням навколишніх тканин яєчника через саму наявність кісти [65].

Метааналіз показав, що в одних і тих же пацієнтів ПАФ у яєчнику з ендометріомою був нижчий як до, так і після хірургічного видалення ендометріоми, ніж у контралатеральному інтактному яєчнику [66].

Якщо лікування не розпочато на ранній стадії, майже кожне хірургічне втручання для усунення ендометріоми неминуче призводить до зменшення резерву яєчника часто супроводжується рецидивом. Якщо жінка зазнає повторної операції з приводу рецидиву ендометріоми, то це неминуче викличе серйозні пошкодження оваріального резерву [67]. Однак не було досягнуто консенсусу щодо термінів проведення операцій у молодих жінок із безпліддям: чи слід відкласти операцію у тих, у кого планується ЕКЗ [68].

Проміжок часу від початку менархе до часу формування ендометріоми, яка вимагає хірургічного втручання, оцінюється як мінімум 4 роки $[69,14]$, а застосування хірургії з ексцизією капсули ендометріоми може привести у молодих жінок, навіть у підлітків, до значного зниження оваріального резерву.

Шляхи збереження оваріального резерву

Звичайно ж, лапароскопія залишається на сьогодні методом вибору для лікування ендометріозу, зокрема ендометріоми яєчника, коли показано ії хірургічне видалення [56, 70]. Враховуючи те, що використання коагуляції для гемостазу завдає шкоди фоолікулярному резерву, способом його збереження $є$ використання шовного матеріалу, який дає після стрипінгу кращий результат збереження оваріального резерву [71, 72]. При необхідності використання методу біполярної енергії для гемостазу сильно кровоточивих судин потрібно дотримуватися принципу мінімального його використання точковим способом, а також застосовувати його якомога далі від яєчникових воріт і по можливості рідше.

Ще однією перспективною методикою збереження оваріального резерву є PRP-терапія з аутологічної крові. Плазма, збагачена тромбоцитами (platelet rich plasma PRP), являє собою концентроване джерело тромбоцитів, отримане з венозної крові після іїі центрифугування [73]. Цей концентрат як унікальна система містить в собі понад 800 типів білкових молекул, цитокінів, гормонів і хемоатрактантів [74]. Активація тромбоцитів, що потрапили в тканини, викликає виділення різноманітних біологічно активних білків, які стимулюють проліферацію, ріст і дисеренціювання клітин [75]. PRP викликає прискорений ангіогенез і анаболізм, міграцію клітин, дисреренціювання та проліферацію [76]. Також було показано, що PRP сприяє розвитку ізольованих примордіальних і первинних фролікулів людини до преантральної стадії [77]. Таким чином, цю унікальну аутологічну систему можна застосувати інтраопераційно, враховуючи оперативні наслідки лапароскопії.

Склеротерапія також є одним із перспективних методів лікування ендометріом [78]. Суть її полягає в аспірації вмісту кісти та введенні склерозуючої речовини в її порожнину. Цей механізм полягає в тому, що склерозант потрапляючи в порожнину кісти, пошкоджує епітеліальне вистилання кісти з наступним запаленням і фріброзом, що в підсумку приводить до облітерації кісти [79]. Було показано, що склеротерапія ефективна й економічно вигідна процедура для жінок з ендометріомою яєчника [80]. Ï̈̈ вплив на оваріальний резерв мінімальний або відсутній, що підтверджується дослідженнями, де після склеротерапії етанолом показники ПАФ значно покращилися $[60,81,82]$.

Частота рецидивів ендометріоми після склеротерапії коливалася від 0 до 62,5 \% [3]. Перевага склеротерапії як операції для збереження оваріального резерву була показана у жінок із первинною та повторною операціями на яєчниках. Як ПАФ, так і рівень АМГ в сироватці крові підвищувалися після проведення склеротерапії [60, 82].

ВИсновки. За допомогою запропонованих методів лікування можна буде досягти збереження оваріального резерву в жінок зі зниженим оваріальним резервом внаслідок ендометріоїдних кіст, тим самим збільшивши можливість настання у них спонтанної вагітності або вагітності за допомогою ДРТ.

\section{СПИСОК ЛІТЕРАТУРИ}

1. Macer M. Endometriosis and infertility: A review of the pathogenesis and treatment of endometriosis-associated infertility / M. Macer, H. Taylor // Obstet. Gynecol. Clin. North. Am. - 2012. - Vol. 39 (4). - P. 535-549.

2. Spectrum of symptoms in women diagnosed with endometriosis during adolescence vs adulthood / A. Di Vasta, A. F. Vitonis, M. R. Laufer, S. A. Missmer // Am. J. Obstet. Gynecol. - 2018. - Vol. 218 (3). - P. 324.e1-324.e11.

3. The efficacy of postoperative cyclic oral contraceptives after gonadotropin-releasing hormone agonist therapy to prevent endometrioma recurrence in adolescents / J. W. Seo, D. Y. Lee, B. K. Yoon, D. Choi // J. Pediatr. Adolesc. Gynecol. - 2017. Vol. 30 (2). - P. 223-227.

4. Gordts S. Pathogenesis of deep endometriosis / S. Gordts, P. Koninckx, I. Brosens // Fertil. Steril. - 2017. - Vol. 108 (6). - P. 872-885.e1.

5. Management of ovarian endometriomas / C. Chapron, Y. Wang, X. Liu, D. L. Olive // Hum. Reprod. Update. - 2002. Vol. 8 (6). - P. 591-597.

6. Treatment of pelvic pain associated with endometriosis: a 
committee opinion / Practice Committee of the American Society for Reproductive Medicine // Fertil. Steril. - 2014. - Vol. 101 (4) - P. 927-935.

7. Laterality and asymmetry of endometriotic lesions / S. W. Guo, Y. Wang, X. Liu, D. L. Olive // Fertil. Steril. - 2008. - Vol. 89 (1). - P. 33-41.

8. Maggiore U.L.R. Treatment of endometrioma for improving fertility / U.L.R. Maggiore, J. K. Gupta, S. Ferrero // Eur. J. Obstet. Gynecol. Reprod. Biol. - 2017. - Vol. 209. - P. 81-85.

9. Brosens I. The endoscopic localization of endometrial implants in the ovarian chocolate cyst / I. Brosens, P. Puttemans, J. Deprest // Fertil. Steril. - 1994. - Vol. 61 (6). - P. 1034-1038.

10. Large ovarian endometriomas / J. Donnez, M. Nisolle, N. Gillet [et al.] // Hum. Reprod. - 1996. - Vol. 11 (3). P. 641-645

11. Clinical and histologic classification of endometriomas. Implications for a mechanism of pathogenesis / F. Nezhat, C. Nezhat, C. J. Allan [et al.] // J. Reprod. Med. - 1992. Vol. 37 (9). - P. 771-776.

12. Bałkowiec M. The bimodal role of matrix metalloproteinases and their inhibitors in etiology and pathogenesis of endometriosis (Review) / M. Bałkowiec, R. Maksym, P. Włodarski // Mol. Med. Rep. - 2018. - Vol. 18 (3). - P. 3123-3136.

13. Important initiative roles of CD44 and tenascin in Sampson's theory of the pathogenesis and development of endometriosis / S. Igarashi, T. Igarashi, Y. Abe [et al.] // J. Endometr. Pelvic. Pain. Disord. - 2013. - Vol. 5 (3). - P. 100-104.

14. Wright K. Endometriomas in adolescents / K. Wright, M. Laufer // Fertil. Steril. - 2010. - Vol. 94 (4). - P. 1529 e7-1529.e9.

15. High serum follistatin levels in women with ovarian endometriosis / P. Florio, F. M. Reis, P. B. Torres [et al.] // Hum. Reprod. - 2009. - Vol. 24 (10). - P. 2600-2606.

16. Baker T. G. A quantitative and cytological study of germ cells in human ovaries / T. G. Baker // Proc. R. Soc. Lond. B. Biol. Sci. - 1963. - Vol. 158 (972). - P. 417-433.

17. Block E. Quantitative morphological investigations of the follicular system in women / E. Block // Cells Tissues Organs. 1952. - Vol. 14 (1-2). - P. 108-123.

18. Faddy M. Accelerated disappearance of ovarian follicles in mid-life: implications for forecasting menopause / M. Faddy, R. G. Gosden, A. Gougeon [et al.] // Hum. Reprod. - 1992. Vol. 7 (10). - P. 1342-1346.

19. Sanchez A. The distinguishing cellular and molecular features of the endometriotic ovarian cyst: from pathophysiology to the potential endometrioma-mediated damage to the ovary / A. Sanchez, P. Viganò, E. Somigliana [et al.] // Hum. Reprod. Update. - 2013. - Vol. 20 (2). - P. 217-230.

20. Ovarian endometrioma in the adolescent: a plea for early-stage diagnosis and full surgical treatment / S. Gordts, P. Puttemans, S. Gordts, I. Brosens // Gynecol. Surg. - 2015 - Vol. 12 (1). - P. 21-30.

21. The effect of surgery for endometriomas on fertility // BJOG. - 2017. - Vol. 125 (6). - P. e19-e28.

22. Morphodynamics of the follicular-luteal complex during early ovarian development and reproductive life / P. M. Motta, S. A. Nottola, G. Familiari [et al.] // Int. Rev. Cytol. - 2002. Vol. 223. - P. 177-288.

23. Oktem $\mathrm{O}$. Understanding follicle growth in vivo / O. Oktem, B. Urman // Hum. Reprod. - 2010. - Vol. 25 (12). P. 2944-2954.

24. Contents of endometriotic cysts, especially the high concentration of free iron, are a possible cause of carcinogenesis in the cysts through the iron-induced persistent oxidative stress / K. Yamaguchi, S. A. Nottola, G. Familiari [et al.] // Clin. Cancer Res. - 2008. - Vol. 14 (1). - P. 32-40.
25. Iron availability is increased in individual human ovarian follicles in close proximity to an endometrioma compared with distal ones / A. Sanchez, E. Papaleo, L. Corti [et al.] // Hum. Reprod. - 2014. - Vol. 29 (3). - P. 577-583

26. Morphological features of uterine polyps in females of reproductive age / N. Y. Gorban, T. D. Zadorozhna, I. B. Vovk, I. V. Zhulkevych // Вісник наукових досліджень. - 2019. № 2. - C. 47-52.

27. Matsuzaki S. Oxidative stress status in normal ovarian cortex surrounding ovarian endometriosis / S. Matsuzaki, B. Schubert // Fertil. Steril. - 2010. - Vol. 93 (7). - P. 2431-2432.

28. Endometriomas as a possible cause of reduced ovarian reserve in women with endometriosis / M. Kitajima, S. Defrère, M. M. Dolmans [et al.] // Fertil. Steril. - 2011. - Vol. 96 (3). P. 685-691.

29. Enhanced follicular recruitment and atresia in cortex derived from ovaries with endometriomas / M. Kitajima, M. M. Dolmans, O. Donnez [et al.] // Fertil. Steril. - 2014. Vol. 101 (4). - P. 1031-1037.

30. Peculiarities of uterine cavity biocenosis in patients with different types of endometrial hyperproliferative pathology / N. Y. Horban, I. B. Vovk, T. O. Lysiana [et al.] // J. Med. Life. 2019. - Vol. 12 (3). - P. 266-270.

31. Human ovarian tissue from cortex surrounding benign cysts: a model to study ovarian tissue cryopreservation / B. Schubert, M. Canis, C. Darcha [et al.] // Hum. Reprod. - 2005. - Vol. 20 (7). - P. 1786-1792.

32. The effect of laparoscopic ovarian cystectomy versus coagulation in bilateral endometriomas on ovarian reserve as determined by antral follicle count and ovarian volume: a prospective randomized study / T. Var, S. Batioglu, E. Tonguc [et al.] // Fertil. Steril. - 2011. - Vol. 95 (7). - P. 2247-2250.

33. The antral follicle count: practical recommendations for better standardization / F. Broekmans, D. de Ziegler, C. M. Howles [et al.] // Fertil. Steril. - 2010. - Vol. 94 (3). P. 1044-1051.

34. Iliodromiti S. Technical and performance characteristics of anti-Müllerian hormone and antral follicle count as biomarkers of ovarian response / S. Iliodromiti, R. Anderson, S. Nelson // Hum. Reprod. Update. - 2014. - Vol. 21 (6). - P. 698-710.

35. Seifer D. Is AMH a regulator of follicular atresia? / D. Seifer, Z. Merhi // J. Assist. Reprod. Genet. - 2014. - Vol. 31 (11). - P. 1403-1407

36. Ultrasonographic evaluation and anti-mullerian hormone levels after laparoscopic stripping of unilateral endometriomas / C. M. Ercan, N. K. Duru, K. E. Karasahin [et al.] // Eur. J. Obstet. Gynecol. Reprod. Biol. - 2011. - Vol. 158 (2). - P. 280-284.

37. Proteolytic processing of mullerian inhibiting substance produces a transforming growth factor-beta-like fragment / R. B. Pepinsky, L. K. Sinclair, E. P. Chow [et al.] // J. Biol. Chem. - 1988. - Vol. 263 (35). - P. 18961-18964.

38. Visser J. Anti-Müllerian hormone and folliculogenesis / J. Visser, A. Themmen // Mol. Cell. Endocrinol. - 2005. Vol. 234 (1-2). - P. 81-86.

39. Expression of anti-Müllerian hormone during normal and pathological gonadal development: Association with Differentiation of Sertoli and Granulosa Cells / E. Rajpert-De Meyts, N. Jørgensen, N. Graem [et al.] // J. Clin. Endocrinol. Metab. - 1999. - Vol. 84 (10). - P. 3836-3844.

40. Anti-Müllerian hormone attenuates the effects of fsh on follicle development in the mouse ovary / A. Durlinger, M. J. Gruijters, P. Kramer [et al.] // Endocrinology. - 2001. - Vol. 142 (11). - P. 4891-4899.

41. The aromatase inhibitor letrozole increases the concentration of intraovarian androgens and improves in vitro fertilization outcome in low responder patients: A pilot study / 
J. Garcia-Velasco, L. Moreno, A. Pacheco [et al.] // Fertil. Steril. - 2005. - Vol. 84 (1). - P. 82-87.

42. Which follicles make the most anti-Mullerian hormone in humans? Evidence for an abrupt decline in $\mathrm{AMH}$ production at the time of follicle selection / J. Jeppesen, R. A. Anderson, T. W. Kelsey [et al.] // Mol. Hum. Reprod. - 2013. - Vol. 19 (8). - P. 519-527.

43. La Marca A. How much does AMH really vary in normal women? / A. La Marca, V. Grisendi, G. Griesinger // Int. J. Endocrinol. - 2013. - Vol. 2013. - P. 1-8.

44. Normal serum anti-Müllerian hormone levels in the general female population and the relationship with reproductive history / A. La Marca, E. Spada, V. Grisendi [et al.] // Eur. J. Obstet. Gynecol. Reprod. Biol. - 2012. - Vol. 163 (2). - P. 180-184.

45. Fluctuations in anti-Müllerian hormone levels throughout the menstrual cycle parallel fluctuations in the antral follicle count: a cohort study / M. Depmann, J. van Disseldorp, S. L. Broer [et al.] // Acta Obstet. Gynecol. Scand. - 2016. Vol. 95 (7). - P. 820-828.

46. Assessing ovarian response: antral follicle count versus anti-Müllerian hormone / R. Fleming, D. B. Seifer, J. L. Frattarelli, J. Ruman // Reprod. BioMed. Online. - 2015. - Vol. 31 (4). - P. 486-496.

47. The cohort of antral follicles measuring 2-6 mm reflects the quantitative status of ovarian reserve as assessed by serum levels of anti-Müllerian hormone and response to controlled ovarian stimulation / K. Jayaprakasan, S. Deb, M. Batcha [et al.] // Fertil. Steril. - 2010. - Vol. 94 (5). - P. 1775-1781.

48. Baerwald A. Ovarian antral folliculogenesis during the human menstrual cycle: a review / A. Baerwald, G. Adams, R. Pierson // Hum. Reprod. Update. - 2011. - Vol. 18 (1). P. 73-91.

49. Intracycle variation in number of antral follicles stratified by size and in endocrine markers of ovarian reserve in women with normal ovulatory menstrual cycles / S. Deb, B. K. Campbell, J. S. Clewes [et al.] // Ultrasound Obstet. Gynecol. - 2013. Vol. 41 (2). - P. 216-222.

50. Vandekerckhove F. The Value of automated follicle volume measurements in IVF/ICSI / F. Vandekerckhove, V. Bracke, P. De Sutter // Front. Surg. - 2014. - Vol. 1. - P. 18.

51. Arce $\mathrm{J}$. The rate of high ovarian response in women identified at risk by a high serum AMH level is influenced by the type of gonadotropin / J. Arce, B. Klein, A. La Marca // Gynecol. Endocrinol. - 2014. - Vol. 30 (6). - P. 444-450.

52. Can anti-Müllerian hormone concentrations be used to determine gonadotrophin dose and treatment protocol for ovarian stimulation? / R. Fleming, F. Broekmans, C., CalhazJorge [et al.] // Reprod. Biomed. Online. - 2013. - Vol. 26 (5). P. 431-439.

53. Use of ovarian reserve parameters for predicting live births in women undergoing in vitro fertilization / K. Lukaszuk, M. Kunicki, J. Liss [et al.] // Eur. J. Obstet. Gynecol. Reprod. Biol. - 2013. - Vol. 168 (2). - P. 173-177.

54. Predictors of ovarian response in women treated with corifollitropin alfa for in vitro fertilization/intracytoplasmic sperm injection / N. Polyzos, H. Tournaye, L. Guzman [et al.] // Fertil. Steril. - 2013. - Vol. 100 (2). - P. 430-437.

55. Grisendi V. Ovarian reserve markers to identify poor responders in the context of poseidon classification / V. Grisendi, E. Mastellari, A. La Marca // Front. Endocrinol. (Lausanne). 2019. - Vol. 10. - P. 281.

56. Impact of unilateral versus bilateral ovarian endometriotic cystectomy on ovarian reserve: a systematic review and metaanalysis / S. Johnny, N. S. Younis, R. Fleming [et al.] // Hum. Reprod. Update. - 2019. - Vol. 25 (3). - P. 375-391.
57. Excisional surgery versus ablative surgery for ovarian endometriomata / R. J. Hart, M. Hickey, P. Maouris, W. Buckett // Cochrane Database Syst. Rev. - 2008. - No. 2. -CD004992. Access mode : https://doi.org/10.1002/14651858.CD004992.pub3.

58. ESHRE guideline: management of women with endometriosis / G. Dunselman, N. Vermeulen, C. Becker [et al.] // Hum. Reprod. - 2014. - Vol. 29 (3). - P. 400-412.

59. Rate of severe ovarian damage following surgery for endometriomas / L. Benaglia, E. Somigliana, V. Vighi [et al.] // Hum. Reprod. - 2010. - Vol. 25 (3). - P. 678-682.

60. Raffi F. The impact of excision of ovarian endometrioma on ovarian reserve: A Systematic Review and Meta-Analysis / F. Raffi, M. Metwally, S. Amer // J. Clin. Endocrinol. Metab. 2012. - Vol. 97 (9). - P. 3146-3154.

61. Ethanol sclerotherapy: a treatment option for ovarian endometriomas before ovarian stimulation / C. Yazbeck, P. Madelenat, J. P. Ayel [et al.] // Reprod. Biomed. Online. 2009. - Vol. 19 (1). - P. 121-125.

62. Laparoscopic removal of endometriomas: sonographic evaluation of residual functioning ovarian tissue / C. Exacoustos, E. Zupi, A. Amadio [et al.] // Am. J. Obstet. Gynecol. - 2004. Vol. 191 (1). - P. 68-72.

63. Hemostasis by bipolar coagulation versus suture after surgical stripping of bilateral ovarian endometriomas: A randomized controlled trial / S. Ferrero, P. L. Venturini, D. J. Gillott [et al.] // J. Minim. Invasive Gynecol. - 2012. - Vol. 19 (6). - P. 722-730.

64. Effects of bipolar electrocoagulation versus suture after laparoscopic excision of ovarian endometrioma on the ovarian reserve and outcome of in vitro fertilization / A. Takashima, N. Takeshita, K. Otaka, T. Kinoshita // J. Obstet. Gynaecol. Res. - 2013. - Vol. 39 (7). - P. 1246-1252.

65. Zaitoun M. Comparing long term impact on ovarian reserve between laparoscopic ovarian cystectomy and open laprotomy for ovarian endometrioma / M. Zaitoun, M. Zaitoun, M. El Behery // J. Ovarian Res. - 2013. - Vol. 6 (1). - P. 76.

66. Antimüllerian hormone is reduced in the presence of ovarian endometriomas: a systematic review and meta-analysis / L. Muzii, C. Di Tucci, M. Di Feliciantonio [et al.] // Fertil. Steril. - 2018. - Vol. 110 (5). - P. 932-940.e1.

67. The effect of surgery for endometrioma on ovarian reserve evaluated by antral follicle count: a systematic review and meta-analysis / L. Muzii, C. Di Tucci, M. Di Feliciantonio [et al.] // Hum. Reprod. - 2014. - Vol. 29 (10). - P. 2190-2198.

68. Second surgery for recurrent endometriomas is more harmful to healthy ovarian tissue and ovarian reserve than first surgery / L. Muzii, C. Achilli, F. Lecce [et al.] // Fertil. Steril. 2015. - Vol. 103 (3). - P. 738-743.

69. Ruiz-Flores F. Is there a benefit for surgery in endometrioma-associated infertility? / F. Ruiz-Flores, J. Garcia-Velasco // Curr. Opin. Obstet. Gynecol. - 2012. - Vol. 24 (3). - P. 136-140.

70. Recurrence of ovarian endometrioma in adolescents after conservative, laparoscopic cyst enucleation / S. Y. Lee, M. L. Kim, S. J Seong, [et al.] // J. Pediatr. Adoles. Gynecol. 2017. - Vol. 30 (2). - P. 228-233.

71. Management of presumed benign ovarian tumors: updated French guidelines / J. L. Brun, X. Fritel, Y. Aubard [et al.] // Eur. J. Obstet. Gynecol. Reprod. Biol. - 2014. - Vol. 183. P. 52-58.

72. Comparing ovarian reserve after laparoscopic excision of endometriotic cysts and hemostasis achieved either by bipolar coagulation or suturing: a randomized clinical trial / Z. Asgari, S. Rouholamin, R. Hosseini [et al.] // Arch. Gynecol. Obstet. 2015. - Vol. 293 (5). - P. 1015-1022.

73. The impact on ovarian reserve of different hemostasis methods in laparoscopic cystectomy: A systematic review and 
meta-analysis / C. Baracat, H. Abdalla-Ribeiro, R. Araujo [et al.] // Rev. Bras. Ginecol. Obstet. - 2019. - Vol. 41 (06). P. $400-408$

74. Pietrzak W. Platelet rich plasma: Biology and new technology / W. Pietrzak, B. Eppley // J. Craniofac. Surg. - 2005. - Vol. 16 (6). - P. 1043-1054.

75. Dhurat R. Principles and methods of preparation of platelet-rich plasma: A review and author's perspective / R. Dhurat, M. Sukesh // J. Cutan. Aesthet. Surg. - 2014. Vol. 7 (4). - P. 189.

76. The anti-inflammatory and matrix restorative mechanisms of platelet-rich plasma in osteoarthritis / E. Sundman, B. J. Cole, V. Karas [et al.] // Am. J. Sports Med. - 2013. Vol. 42 (1). - P. 35-41.

77. Effect of platelet-rich plasma (PRP) concentration on the viability and proliferation of alveolar bone cells: an in vitro study / B. H. Choi, S. J. Zhu, B. Y. Kim [et al.] // Int. J. Oral Maxillofac. Surg. - 2005. - Vol. 34 (4). - P. 420-424.

78. Platelet-rich plasma promotes the development of isolated human primordial and primary follicles to the preantral stage / L. Hosseini, A. Shirazi, M. M. Naderi [et al.] // Reprod. BioMed. Online. - 2017. - Vol. 35 (4). - P. 343-350.

\section{REFERENCES}

1. Macer, M. L., \& Taylor, H. S. (2012). Endometriosis and infertility: A review of the pathogenesis and treatment of endometriosis-associated infertility. Obstet. Gynecol. Clin. North. Am., 39 (4), 535-549.

2. DiVasta, A.D., Vitonis, A.F., Laufer, M.R., \& Missmer, S.A. (2018). Spectrum of symptoms in women diagnosed with endometriosis during adolescence vs adulthood. Am. J. Obstet. Gynecol., 218 (3), 324.e1-324.e11.

3. Seo, J.W., Lee, D.Y., Yoon, B.K., \& Choi, D. (2017) The efficacy of postoperative cyclic oral contraceptives after gonadotropin-releasing hormone agonist therapy to prevent endometrioma recurrence in adolescents. J. Pediatr. Adolesc. Gynecol., 30 (2), 223-227.

4. Gordts, S., Koninckx, P., \& Brosens, I. (2017). Pathogenesis of deep endometriosis. Fertil. Steril., 108 (6), 872-885.e1.

5. Chapron, C., Vercellini, P., Barakat, H., Vieira, M., \& Dubuisson, J.B. (2002). Management of ovarian endometriomas. Hum. Reprod. Update., 8 (6), 591-597.

6. Practice Committee of the American Society for Reproductive Medicine (2014). Treatment of pelvic pain associated with endometriosis: a committee opinion. Fertil. Steril., 101 (4), 927-935.

7. Guo, S.W., Wang, Y., Liu, X., \& Olive, D.L. (2008). Laterality and asymmetry of endometriotic lesions. Fertil. Steril., 89 (1), 33-41.

8. Maggiore, U.L.R., Gupta, J.K., \& Ferrero, S. (2017). Treatment of endometrioma for improving fertility. Eur. J. Obstet. Gynecol. Reprod. Biol., 209, 81-85.

9. Brosens, I.A., Puttemans, P.J., \& Deprest, J. (1994). The endoscopic localization of endometrial implants in the ovarian chocolate cyst. Fertil. Steril., 61 (6), 1034-1038.

10. Donnez, J., Nisolle, M., Gillet, N., Smets, M., Bassil, S., \& Casanas-Roux, F. (1996). Large ovarian endometriomas. Hum. Reprod., 11 (3), 641-646.

11. Nezhat, F., Nezhat, C., Allan, C.J., Metzger, D.A., \& Sears, D.L. (1992). Clinical and histologic classification of endometriomas. Implications for a mechanism of pathogenesis. J. Reprod. Med., 37 (9), 771-776.

12. Bałkowiec, M., Maksym, R.B., \& Włodarski, P.K. (2018). The bimodal role of matrix metalloproteinases and their inhibitors
79. Preliminary results: ethanol sclerotherapy after ultrasound-guided fine needle aspiration without anesthesia in the management of simple ovarian cysts / V. M. Castellarnau, S. J. Ponce, C. R. Carreras [et al.] // J. Minim. Invasive Gynecol. - 2015 - Vol. 22 (3). - P. 475-482.

80. Albanese G. Pharmacology of Sclerotherapy / G. Albanese, K. Kondo // Semin. Interven. Radiol. - 2010. - Vol. 27 (4). - P. 391-399.

81. Laparoscopic findings after ultrasound-guided transvaginal ethanol sclerotherapy for ovarian endometrial cyst I R. Okagaki, Y. Osuga, M. Momoeda [et al.] // Hum. Reprod. 1999. - Vol. 14 (1). - P. 270-270.

82. Hsieh C. Effectiveness of ultrasound-guided aspiration and sclerotherapy with $95 \%$ ethanol for treatment of recurrent ovarian endometriomas / C. L. Hsieh, C. S. Shiau, L. M. Lo [et al.] // Fertil. Steril. - 2009. - Vol. 91 (6). - P. 2709-2713.

83. Surgical resection or aspiration with ethanol sclerotherapy of endometrioma beforein vitrofertilization in infertilie women with endometrioma / K. Lee, C. H. Kim, Y. J. Lee [et al.] // Obstet. Gynecol. Sci. - 2014. - Vol. 57 (4). - P. 297.

84. Cohen A. Sclerotherapy in the management of ovarian endometrioma: systematic review and meta-analysis /A. Cohen, B. Almog, T. Tulandi // Fertil. Steril. - 2017. - Vol. 108 (1). - P. 117-124.e5.

in etiology and pathogenesis of endometriosis (Review). Mol. Med. Rep., 18 (3), 3123-3136.

13. Igarashi, S., Igarashi, T., Abe, Y., Liang, S.-G., Minegishi, T., \& Igarashi, M. (2013). Important initiative roles of CD44 and tenascin in Sampson's theory of the pathogenesis and development of endometriosis. J. Endometr. Pelvic. Pain. Disord., 5, 100-104.

14. Wright, K.N., \& Laufer, M.R. (2010). Endometriomas in adolescents. Fertil. Steril., 94 (4), 1529.e7-1529.e1.529E19.

15. Florio, P., Reis, F.M., Torres, P.B., Calonaci, F., Abrao, M.S., Nascimento, L.L., ..., \& Petraglia, F. (2009). High serum follistatin levels in women with ovarian endometriosis. Hum. Reprod., 24 (10), 2600-2606.

16. Baker, T.G. (1963). A quantitative and cytological study of germ cells in human ovaries. Proc. R. Soc. Lond. B. Biol. Sci., 158, 417-433.

17. Block E. (1952). Quantitative morphological investigations of the follicular system in women / E. Block // Cells Tissues Organs, 14 (1-2), 108-123.

18. Faddy, M.J., Gosden, R.G., Gougeon, A., Richardson, S.J., \& Nelson, J.F. (1992). Accelerated disappearance of ovarian follicles in mid-life: implications for forecasting menopause. Hum. Reprod., 7 (10), 1342-1346.

19. Sanchez, A.M., Viganò, P., Somigliana, E., Panina-Bordignon, P., Vercellini, P., \& Candiani, M. (2014). The distinguishing cellular and molecular features of the endometriotic ovarian cyst: from pathophysiology to the potential endometrioma-mediated damage to the ovary. Hum. Reprod. Update., 20 (2), 217-230.

20. Gordts, S., Puttemans, P., Gordts, S., \& Brosens, I. (2015). Ovarian endometrioma in the adolescent: a plea for early-stage diagnosis and full surgical treatment. Gynecol. Surg., 12 (1), 21-30.

21 . The effect of surgery for endometriomas on fertility (2018). BJOG, 125 (6), e19-e28.

22. Motta, P.M., Nottola, S.A., Familiari, G., Makabe, S., Stallone, T., \& Macchiarelli, G. (2003). Morphodynamics of the follicular-luteal complex during early ovarian development and reproductive life. Int. Rev. Cytol., 223, 177-288.

23. Oktem, O., \& Urman, B. (2010). Understanding follicle growth in vivo. Hum. Reprod., 25 (12), 2944-2954. 
24. Yamaguchi, K., Mandai, M., Toyokuni, S., Hamanishi, J., Higuchi, T., Takakura, K., \& Fujii, S. (2008). Contents of endometriotic cysts, especially the high concentration of free iron, are a possible cause of carcinogenesis in the cysts through the iron-induced persistent oxidative stress. Clin. Cancer Res., 14 (1), 32-40.

25. Sanchez, A.M., Papaleo, E., Corti, L., Santambrogio, P. Levi, S., Viganò, P., ..., \& Panina-Bordignon, P. (2014). Iron availability is increased in individual human ovarian follicles in close proximity to an endometrioma compared with distal ones. Hum. Reprod., 29 (3), 577-583.

26. Gorban, N.Y., Zadorozhna, T.D., Vovk, I.B., \& Zhulkevych, I.V. (2019). Morphological features of uterine polyps in females of reproductive age. Visnyk naukovykh doslidzhen Bull. Sci. Res., 2, 47-52.

27. Matsuzaki, S., \& Schubert, B. (2010). Oxidative stress status in normal ovarian cortex surrounding ovarian endometriosis. Fertil. Steril., 93 (7), 2431-2432.

28. Kitajima, M., Defrère, S., Dolmans, M.M., Colette, S., Squifflet, J., Van Langendonckt, A., \& Donnez, J. (2011). Endometriomas as a possible cause of reduced ovarian reserve in women with endometriosis. Fertil. Steril., 96 (3), 685-691.

29. Kitajima, M., Dolmans, M.M., Donnez, O., Masuzaki, H., Soares, M., \& Donnez, J. (2014). Enhanced follicular recruitment and atresia in cortex derived from ovaries with endometriomas. Fertil. Steril., 101 (4), 1031-1037.

30. Schubert, B., Canis, M., Darcha, C., Artonne, C., Pouly, J. L., Déchelotte, P., ..., \& Grizard, G. (2005). Human ovarian tissue from cortex surrounding benign cysts: a model to study ovarian tissue cryopreservation. Hum. Reprod., 20 (7), 1786-1792.

31. Horban, N.Y., Vovk, I.B., Lysiana, T.O., Ponomariova, I.H., \& Zhulkevych, I.V. (2019). Peculiarities of uterine cavity biocenosis in patients with different types of endometrial hyperproliferative pathology. J. Med. Life, 12 (3), 266-270.

32. Var, T., Batioglu, S., Tonguc, E., \& Kahyaoglu, I. (2011). The effect of laparoscopic ovarian cystectomy versus coagulation in bilateral endometriomas on ovarian reserve as determined by antral follicle count and ovarian volume: a prospective randomized study. Fertil. Steril., 95 (7), 2247-2250.

33. Broekmans, F.J., de Ziegler, D., Howles, C.M., Gougeon, A., Trew, G., \& Olivennes, F. (2010). The antral follicle count: practical recommendations for better standardization. Fertil. Steril., 94 (3), 1044-1051.

34. Iliodromiti, S., Anderson, R.A., \& Nelson, S.M. (2015). Technical and performance characteristics of anti-Müllerian hormone and antral follicle count as biomarkers of ovarian response. Hum. Reprod. Update, 21 (6), 698-710.

35. Seifer, D.B., \& Merhi, Z. (2014). Is AMH a regulator of follicular atresia? J. Assist. Reprod. Genet., 31 (11), 1403-1407.

36. Ercan, C.M., Duru, N.K., Karasahin, K.E., Coksuer, H., Dede, M., \& Baser, I. (2011). Ultrasonographic evaluation and anti-mullerian hormone levels after laparoscopic stripping of unilateral endometriomas. Eur. J. Obstet. Gynecol. Reprod. Biol., 158 (2), 280-284.

37. Pepinsky, R.B., Sinclair, L.K., Chow, E.P., Mattaliano, R.J., Manganaro, T.F., Donahoe, P.K., \& Cate, R.L. (1988). Proteolytic processing of mullerian inhibiting substance produces a transforming growth factor-beta-like fragment. J. Biol. Chem., 263 (35), 18961-18964.

38. Visser, J.A., \& Themmen, A.P. (2005). Anti-Müllerian hormone and folliculogenesis. Mol. Cell. Endocrinol., 234 (12), 81-86.

39. Rajpert-De Meyts, E., Jørgensen, N., Graem, N., Müller, J., Cate, R.L., \& Skakkebaek, N.E. (1999). Expression of anti-Müllerian hormone during normal and pathological gonadal development: association with differentiation of Sertoli and granulosa cells. J. Clin. Endocrinol. Metab., 84 (10), 3836-3844.
40. Durlinger, A.L., Gruijters, M.J., Kramer, P., Karels, B., Kumar, T.R., Matzuk, M. M., ..., \& Themmen, A.P. (2001). AntiMüllerian hormone attenuates the effects of FSH on follicle development in the mouse ovary. Endocrinology, 142 (11), 4891-4899.

41. Garcia-Velasco, J.A., Moreno, L., Pacheco, A., Guillén, A., Duque, L., Requena, A., \& Pellicer, A. (2005). The aromatase inhibitor letrozole increases the concentration of intraovarian androgens and improves in vitro fertilization outcome in low responder patients: a pilot study. Fertil. Steril., 84 (1), 82-87.

42. Jeppesen, J.V., Anderson, R.A., Kelsey, T.W., Christiansen, S.L., Kristensen, S.G., Jayaprakasan, K., ..., \& Yding Andersen, C. (2013). Which follicles make the most anti-Mullerian hormone in humans? Evidence for an abrupt decline in $\mathrm{AMH}$ production at the time of follicle selection. Mol. Hum. Reprod., 19 (8), 519-527.

43. La Marca, A., Grisendi, V., \& Griesinger, G. (2013). How much does $\mathrm{AMH}$ really vary in normal women? Int. J. Endocrinol., 2013, 1-8.

44. La Marca, A., Spada, E., Grisendi, V., Argento, C., Papaleo, E., Milani, S., \& Volpe, A. (2012). Normal serum antiMüllerian hormone levels in the general female population and the relationship with reproductive history. Eur. J. Obstet. Gynecol. Reprod. Biol., 163 (2), 180-184.

45. Depmann M., van DisseldorpJ., Broer, S.L, Eijkemans, M.J., Laven, J.S., Visser, J.A., ..., \& Broekmans, F.J. (2016). Fluctuations in anti-Müllerian hormone levels throughout the menstrual cycle parallel fluctuations in the antral follicle count: a cohort study. Acta Obstet. Gynecol. Scand., 95 (7), 820-828.

46. Fleming, R., Seifer, D.B., Frattarelli, J.L., \& Ruman, J. (2015). Assessing ovarian response: antral follicle count versus anti-Müllerian hormone. Reprod. BioMed. Online., 31 (4), 486-496.

47. Jayaprakasan, K., Deb, S., Batcha, M., Hopkisson, J., Johnson, I., Campbell, B., \& Raine-Fenning, N. (2010). The cohort of antral follicles measuring 2-6 $\mathrm{mm}$ reflects the quantitative status of ovarian reserve as assessed by serum levels of anti-Müllerian hormone and response to controlled ovarian stimulation. Fertil. Steril., 94 (5), 1775-1781.

48. Baerwald, A.R., Adams, G.P., \& Pierson, R.A. (2012). Ovarian antral folliculogenesis during the human menstrual cycle: a review. Hum. Reprod. Update., 18 (1), 73-91.

49. Deb, S., Campbell, B.K., Clewes, J.S., Pincott-Allen, C., \& Raine-Fenning, N.J. (2013). Intracycle variation in number of antral follicles stratified by size and in endocrine markers of ovarian reserve in women with normal ovulatory menstrual cycles. Ultrasound Obstet. Gynecol., 41 (2), 216-222.

50. Vandekerckhove, F., Bracke, V., \& De Sutter, P. (2014). The value of automated follicle volume measurements in IVF/ICSI. Front. Surg., 1, 18. https://doi.org/10.3389/ fsurg.2014.00018

51. Arce, J.C., Klein, B.M., \& La Marca, A. (2014). The rate of high ovarian response in women identified at risk by a high serum AMH level is influenced by the type of gonadotropin. Gynecol. Endocrinol., 30 (6), 444-450.

52. Fleming, R., Broekmans, F., Calhaz-Jorge, C., Dracea, L., Alexander, H., Nyboe Andersen, A., ..., \& de Ziegler, D. (2013). Can anti-Müllerian hormone concentrations be used to determine gonadotrophin dose and treatment protocol for ovarian stimulation? Reprod. Biomed. Online, 26 (5), 431-439.

53. Lukaszuk, K., Kunicki, M., Liss, J., Lukaszuk, M., \& Jakiel, G. (2013). Use of ovarian reserve parameters for predicting live births in women undergoing in vitro fertilization. Eur. J. Obstet. Gynecol. Reprod. Biol., 168 (2), 173-177.

54. Polyzos, N.P., Tournaye, H., Guzman, L., Camus, M., \& Nelson, S.M. (2013). Predictors of ovarian response in women treated with corifollitropin alfa for in vitro fertilization/intracytoplasmic sperm injection. Fertil. Steril., 100 (2), 430-437. 
55. Grisendi, V., Mastellari, E., \& La Marca, A. (2019). Ovarian reserve markers to identify poor responders in the context of poseidon classification. Front. Endocrinol. (Lausanne)., 10, 281.

56. Johnny, S., Younis, N.S., Fleming, R., Ben-Shlomo, I. \& Izhaki, I. (2019). Impact of unilateral versus bilateral ovarian endometriotic cystectomy on ovarian reserve: a systematic review and meta-analysis, Hum. Reprod. Update, 25 (3), 375-391.

57. Hart, R.J., Hickey, M., Maouris, P., \& Buckett, W. (2008). Excisional surgery versus ablative surgery for ovarian endometriomata. Cochrane Database Syst. Rev., (2), CD004992. Retreived from: https://doi.org/10.1002/14651858.CD004992.pub3

58. Dunselman, G.A., Vermeulen, N., Becker, C., CalhazJorge, C., D'Hooghe, T., De Bie, ..., \& Nelen, W. (2014). ESHRE guideline: management of women with endometriosis. Human reproduction (Oxford, England), 29 (3), 400-412. Retreived from: https://doi.org/10.1093/humrep/det457.

59. Benaglia, L., Somigliana, E., Vighi, V., Ragni, G., Vercellini, P., \& Fedele, L. (2010). Rate of severe ovarian damage following surgery for endometriomas. Hum. Reprod., 25 (3), 678-682.

60. Raffi, F., Metwally, M., \& Amer, S. (2012). The impact of excision of ovarian endometrioma on ovarian reserve: a systematic review and meta-analysis. J. Clin. Endocrinol. Metab., 97 (9), 3146-3154.

61. Yazbeck, C., Madelenat, P., Ayel, J.P., Jacquesson, L., Bontoux, L.M., Solal, P., \& Hazout, A. (2009). Ethanol sclerotherapy: a treatment option for ovarian endometriomas before ovarian stimulation. Reprod. Biomed. Online., 19 (1), 121-125.

62. Exacoustos, C., Zupi, E., Amadio, A., Szabolcs, B., De Vivo, B., Marconi, D., ..., \& Arduini, D. (2004). Laparoscopic removal of endometriomas: sonographic evaluation of residual functioning ovarian tissue. Am. J. Obstet. Gynecol., 191 (1), 68-72.

63. Ferrero, S., Venturini, P.L., Gillott, D.J., Remorgida, V., \& Maggiore, U.L.R., (2012). Hemostasis by bipolar coagulation versus suture after surgical stripping of bilateral ovarian endometriomas: a randomized controlled trial. J. Minim. Invasive Gynecol., 19 (6), 722-730.

64. Takashima, A. Takeshita, N. Otaka, K., \& Kinoshita, T. (2013). Effects of bipolar electrocoagulation versus suture after laparoscopic excision of ovarian endometrioma on the ovarian reserve and outcome of in vitro fertilization. J. Obstet. Gynaecol. Res., 39 (7), 1246-1252.

65. Zaitoun, M.M., Zaitoun, M.M., \& El Behery, M.M. (2013). Comparing long term impact on ovarian reserve between laparoscopic ovarian cystectomy and open laprotomy for ovarian endometrioma. J. Ovarian Res., 6 (1), 76.

66. Muzii, L., Di Tucci, C., Di Feliciantonio, M., Galati, G., Di Donato, V., Musella, A., ..., \& Panici, P.B. (2018). Antimüllerian hormone is reduced in the presence of ovarian endometriomas: a systematic review and meta-analysis. Fertil. Steril., 110 (5), 932-940.e1.

67. Muzii, L., Di Tucci, C., Di Feliciantonio, M., Marchetti, C., Perniola, G., \& Panici, P.B. (2014). The effect of surgery for endometrioma on ovarian reserve evaluated by antral follicle count: a systematic review and meta-analysis. Hum. Reprod., 29 (10), 2190-2198.

68. Muzii, L., Achilli, C., Lecce, F., Bianchi, A., Franceschetti, S. Marchetti, C., ..., \& Panici, P.B. (2015). Second surgery for recurrent endometriomas is more harmful to healthy ovarian tissue and ovarian reserve than first surgery. Fertil. Steril., 103 (3), 738-743.

69. Ruiz-Flores, F.J., \& Garcia-Velasco, J.A. (2012). Is there a benefit for surgery in endometrioma-associated infertility? Curr. Opin. Obstet. Gynecol., 24 (3), 136-140.
70. Lee, S.Y., Kim, M.L., Seong, S.J., Bae, J.W., \& Cho, Y.J. (2017). Recurrence of ovarian endometrioma in adolescents after conservative, laparoscopic cyst enucleation. J. Pediatr. Adoles. Gynecol., 30 (2), 228-233.

71. Brun, J.L., Fritel, X., Aubard, Y., Borghese, B., Bourdel, N., Chabbert-Buffet, N., ..., \& Levêque, J. (2014). Management of presumed benign ovarian tumors: updated french guidelines. Eur. J. Obstet. Gynecol. Reprod. Biol., 183, 52-58.

72. Asgari, Z., Rouholamin, S., Hosseini, R., Sepidarkish, M., Hafizi, L., \& Javaheri, A. (2016). Comparing ovarian reserve after laparoscopic excision of endometriotic cysts and hemostasis achieved either by bipolar coagulation or suturing: a randomized clinical trial. Arch. Gynecol. Obstet., 293 (5), 1015-1022.

73. Baracat, C., Abdalla-Ribeiro, H., Araujo, R., Bernando, W.M., \& Ribeiro, P.A. (2019). The impact on ovarian reserve of different hemostasis methods in laparoscopic cystectomy: A systematic review and meta-analysis. Rev. Bras. Ginecol. Obstet., 41 (6), 400-408.

74. Pietrzak, W.S., \& Eppley, B.L. (2005). Platelet rich plasma: biology and new technology. J. Craniofac. Surg., 16 (6), 1043-1054

75. Dhurat, R., \& Sukesh, M. (2014). Principles and methods of preparation of platelet-rich plasma: A review and author's perspective. J. Cutan. Aesthet. Surg., 7 (4), 189-197.

76. Sundman, E.A., Cole, B.J., Karas, V., Della Valle, C., Tetreault, M.W., Mohammed, H.O., \& Fortier, L.A. (2014). The anti-inflammatory and matrix restorative mechanisms of plateletrich plasma in osteoarthritis. Am. J. Sports Med., 42 (1), 35-41.

77. Choi, B.H., Zhu, S.J., Kim, B.Y., Huh, J.Y., Lee, S.H., \& Jung, J.H. (2005). Effect of platelet-rich plasma (PRP) concentration on the viability and proliferation of alveolar bone cells: an in vitro study. Int. J. Oral Maxillofac. Surg., 34 (4), 420-424.

78. Hosseini, L., Shirazi, A., Naderi, M.M., Shams-Esfandabadi, N., Borjian Boroujeni, S., Sarvari, A., ..., \& Akhondi, M.M. (2017). Platelet-rich plasma promotes the development of isolated human primordial and primary follicles to the preantral stage. Reprod. BioMed. Online., 35 (4), 343-350.

79. Castellarnau, V.M., Ponce, S.J., Carreras, C.R., Cayuela, F.E., \& Garcia, T.A., (2015). Preliminary results: ethanol sclerotherapy after ultrasound-guided fine needle aspiration without anesthesia in the management of simple ovarian cysts. J. Minim. Invasive Gynecol., 22 (3), 475-482.

80. Albanese, G., \& Kondo, K.L. (2010). Pharmacology of sclerotherapy. Semin. Interven. Radiol., 27 (4), 391-399.

81. Okagaki, R., Osuga, Y., Momoeda, M., Tsutsumi, O., \& Taketani, Y. (1999). Laparoscopic findings after ultrasoundguided transvaginal ethanol sclerotherapy for ovarian endometrial cyst. Hum. Reprod., 14 (1), 270.

82. Hsieh, C.L., Shiau, C.S., Lo, L.M., Hsieh, T.T., \& Chang, M.Y. (2009). Effectiveness of ultrasound-guided aspiration and sclerotherapy with $95 \%$ ethanol for treatment of recurrent ovarian endometriomas. Fertil. Steril., 91 (6), 2709-2713.

83. Lee, K.H., Kim, C.H., Lee, Y.J., Kim, S.H., Chae, H.D., \& Kang, B.M. (2014). Surgical resection or aspiration with ethanol sclerotherapy of endometrioma before in vitro fertilization in infertilie women with endometrioma. Obstet. Gynecol. Sci., 57 (4), 297-303.

84. Cohen, A., Almog, B., \& Tulandi, T. (2017). Sclerotherapy in the management of ovarian endometrioma: systematic review and meta-analysis. Fertil. Steril., 108 (1), 117-124.e5.

Отримано 15.05.20

Прийнято до друку 16.06.20

Електронна адреса для листування: doctorasadsadullaev@gmail.com 